\title{
EMPOWERMENT STRATEGY OF VILLAGE COMMUNITY BASED ON FRESHWATER AQUACULTURE
}

\author{
Dewi Ayu Hidayati ${ }^{1}$, Tina Kartika ${ }^{1}$, and Mohammad Muhassin ${ }^{2}$
}

${ }^{1}$ Faculty of Social and Political Sciences, University of Lampung

${ }^{2}$ Faculty of Education and Teacher Training, Universitas Islam Negeri Raden Intan Lampung

E-mail: dewiayuhidayati@gmail.com; tina.kartika@fisip.unila.ac.id; mohammadmuhasin@radenintan.ac.id

\begin{abstract}
Community empowerment is how to make people have the ability and independence in utilizing the existing potentials. In Banding Agung Village, Pesawaran Lampung, the abundant water resources available can be used for freshwater aquaculture activity as a strategy for empowering the community. The study aims to explore the strategies of community empowerment based on freshwater aquaculture activity, and to find out the factors inhibiting the community empowerment. This is a kind of descriptive qualitative research using case study framework. The data were collected through in-depth interviews, observation, and documentation and analyzed qualitatively employing data reduction, data display, and data verification. The findings indicated that some strategies have been implemented in empowering the community based on the freshwater aquaculture activity, consisting of building the community awareness on the importance of fish farming group (pokdakan), building institutional capacity through education, training and workshop of fish farming management, and putting group members' knowledge and skill into practice. In the implementation of the strategies, some obstacles were found as the factors inhibiting the community empowerment, namely lack of community participation, lack of knowledge and capital, minimum assistance and counseling, and less involvement of the village government. The study recommends several alternative actions for a better implementation of the community empowerment.
\end{abstract}

Key words: community empowerment; freshwater fish; aquaculture; Bandung Agung Village Pesawaran

\section{STRATEGI PEMBERDAYAAN MASYARAKAT DESA BERBASIS BUDIDAYA IKAN AIR TAWAR}

\begin{abstract}
ABSTRAK. Pemberdayaan masyarakat merupakan cara agar masyarakat memiliki kemampuan dan kemandirian dalam memanfaatkan potensi yang ada. Di Desa Banding Agung, Pesawaran Lampung, sumber daya air yang melimpah dapat dimanfaatkan untuk pemberdayaan masyarakat berbasis budidaya air tawar. Penelitian ini bertujuan untuk menggali pemberdayaan masyarakat berbasis budidaya air tawar di Desa Banding Agung, dan mengetahui faktor-faktor penghambat pemberdayaan masyarakat tersebut. Jenis penelitian deskriptif kualitatif dengan kerangka studi kasus. Data dikumpulkan melalui wawancara mendalam, observasi, dan dokumentasi serta dianalisis secara kualitatif dengan reduksi data, display data, dan verifikasi data. Hasil temuan menunjukkan bahwa beberapa strategi telah diterapkan dalam pemberdayaan masyarakat berbasis kegiatan budidaya ikan air tawar, antara lain membangun kesadaran masyarakat akan pentingnya kelompok pembudidaya ikan (pokdakan), membangun kapasitas kelembagaan melalui pendidikan, pelatihan dan lokakarya pengelolaan budidaya ikan, dan mempraktikkan pengetahuan dan keterampilan anggota kelompok. Dalam pelaksanaan strategi tersebut ditemukan beberapa kendala yang menjadi faktor penghambat pemberdayaan masyarakat, yaitu kurangnya partisipasi masyarakat, kurangnya pengetahuan dan modal, minimnya pendampingan dan penyuluhan, serta kurangnya keterlibatan pemerintah desa. Studi ini merekomendasikan beberapa alternatif tindakan untuk implementasi pemberdayaan masyarakat yang lebih baik.
\end{abstract}

Kata kunci: budidaya ikan; ikan air tawar; pemberdayaan masyarakat; Desa Banding Agung Pesawaran

\section{INTRODUCTION}

In the Act 6 of 2014 concerning Villages, it is stated that village development is oriented towards improving the welfare and quality of life of the community, reducing poverty through fulfilling basic needs, developing village facilities and infrastructure, developing local economic potential, and utilizing natural and environmental resources in a sustainable manner. Village development can be done through community empowerment so that they have the ability and independence in exploiting the existing potentials. Community empowerment is a series of activities to optimize competitiveness, especially from the weak groups in society, in order to improve their standard of living and optimize their resources (Ginting, Huda, Drifanda \& Affandi, 2020).

In addition, Prihantoro (2013) asserts that community empowerment can run optimally if it is supported by several factors, such as government participation, the existence of non-governmental organizations, assistance, the presence of local community organizations, education level, and community participation. Furthermore, at the level of implementation, community empowerment can be carried out through several stages, including awareness that they have the right to be able to find solutions to problems faced, increasing their capacity 
through education, training and other activities to improve individual or group skills, and empowerment cultivating the potential that is owned to bring change for better life (Astuti, Hermawan \& Rozikin, 2015).

The fact is that many village community empowerment activities cannot run as expected even though the village is supported by large natural resource potentials. This also happened in Banding Agung Village, Punduh Pidada Subdistrict, Pesawaran Regency Lampung. This village can be said to have considerable natural resources, such as oranges, cocoa, nutmeg, bananas, coffee, rice, vegetables, corn and freshwater. Many obstacles were found in the utilization and management of natural resources so that empowerment activities did not run optimally. The indication was that the results of management were only used for personal consumption and had no economic benefit for increasing welfare.

Of the several potentials that exist in Banding Agung Village, fresh water is one of the most important natural resources because of its abundant availability which can be utilized by the community to carry out freshwater aquaculture. Aquaculture is an effort to maintain and breed fish or other aquatic organisms, such as those found in rice fields, rivers, lakes, ponds and swamps (Squalli, 2020). The success of freshwater aquaculture is largely determined by the environment, namely land and water. The type of soil that is good for freshwater cultivation is the type of clay or loam, while the amount and quality of water must always be a concern so that the freshwater fish farming can be optimal.

Several studies on freshwater aquaculture have been conducted with various focus discussions. At the level of implementation, freshwater fish farming activities can also be combined with water tourism, as is the case in the Lalung Karanganyar reservoir (Setiyawan, 2016). The development of recreational freshwater fish cultivation in Karanganyar is carried out through the arrangement and provision of good physical recreational facilities, coupled with water tourism attractions that are entertaining and educational by utilizing natural potentials such as water and fish as objects.

Fish farming development can also use a SWOT analysis approach like the one carried out in Dimembe Minahasa Utara District (Worang, Sinjal, \& Monijung, 2018). Field findings indicate that internal aspects that influence the development of fish farming in the area include strength factors, namely business location, water quality, support from the local government, the existence of a Freshwater Cultivation Fishery Center, and weakness factors, namely the lack of seed availability and human resources. The external aspects are opportunity factors, namely high fish selling value, high market share, large business opportunities, government policies, and threat factors, namely fishing theft and security. Strategic steps for the development of fish farming in Dimembe District include increasing the production of tilapia and goldfish, providing training on freshwater aquaculture and maintaining the quality of cultivated fish products, making agreements between cultivators in maintaining the safety of aquaculture ponds.

Efforts to improve freshwater fish cultivation results can also be done by managing water quality and making fish feed independently (Sutarjo \& Samsundari, 2018). The results showed that the involvement and active participation of partners was very high in every program implementation including the application of water quality management, making fish feed, and implementing good fish hatchery methods. After a thorough evaluation at the location, the results show that the partners' efforts through training and mentoring activities have a positive impact on partner businesses.

The present research focuses on the exploration of the stages of freshwater aquaculture-based community, as well as the factors inhibiting the community empowerment. In line with the background of problem, this study tries to answer the following questions:

1. What are the strategies implemented in empowering the community based on fresh aquaculture activity in Banding Agung Village?

2. What are the factors inhibiting the community empowerment in Banding Agung Village?

\section{METHOD}

The study was carried out in Banding Agung Village, located in Punduh Pidada Subdistrict, Pesawaran Lampung. The village had abundant water sources which could be utilized as the main asset for the empowerment of freshwater fish farming community. Based on the livelihood strategy, the majority of the people in the village were freshwater aquaculture farmers. In addition, there has been a freshwater aquaculture group as a forum for community members to share knowledge, ability and independence in managing and developing freshwater aquaculture to improve their welfare.

This is a kind of descriptive qualitative research, used to understand the phenomenon about what is experienced by research subjects holistically using descriptive form of spoken or written words, relying 
on the collection of qualitative data (Nassaji, 2015). This research intends to study, describe, and analyze in depth about the stages of community empowerment through freshwater aquaculture in Banding Agung Village to increase freshwater fishery products and encourage the improvement of the economy of the village community and find out the factors inhibiting the community empowerment related to freshwater aquaculture.

This research data were obtained from two main sources, namely primary data as the result of interviews from a number of informants and observations. The secondary data were collected from documentation of several existing media such as books, village documents, and articles related to this research. The determination of informants was done intentionally using purposive sampling technique, in order to obtain data in line with the aims of the study. The informants were the residents of Banding Agung village, consisting of members of fish farming group and local village officials.

The techniques of collecting data included indepth interview, observation, and documentation. The data obtained in the study were then analyzed and explained qualitatively based on the research questions. The data analysis covered some stages of data reduction, data display, and verification (Sugiyono, 2017).

\section{RESULTS AND DISCUSSION}

Banding Agung Village is one of eleven villages located in Punduh Pidada Sub-district, Pesawaran Regency Lampung. Other villages are Bangun Rejo, Batu Raja, Bawang, Java City, Pagar Jawa, Legundi Island, Rubasa, Suka Maju, Sukajaya Pidada, and Sukarame. Banding Agung Village is divided into 2 parts, namely Banding Agung Atas and Banding Agung Bawah which are 4-5 km apart and connected by a hamlet road. The village of Banding Agung has an area of about $10.70 \mathrm{~km} 2$ and a population of 723 people, in other words the population density is 67.57 people / km2 (https://pesawarankab.bps.go.id/).

This village has a lot of natural potentials, including freshwater sources and agricultural commodities such as cocoa, oranges, areca nuts and chilies. One of the great potentials discussed in this study is the abundant water so that almost every yard of the residents' houses has a fish pond which is used for freshwater aquaculture. To improve cultivation yields, Kelompok Budidaya Ikan, the so-called pokdakan was formed to solve various problems related to the freshwater aquaculture. Therefore, this research seeks to investigate and explain the stages of empowerment of freshwater fish farming groups and the obstacles faced in this freshwater fish farming business.

\section{Community Empowerment Strategy Based on Freshwater Aquaculture}

Community empowerment is needed in the development process since both of them are inseparable. Community empowerment is essentially changing people's behavior to a better direction to gradually improve the quality and welfare of their lives. In a broader sense, Laksono (2018) asserts that community empowerment is a process to facilitate and encourage people to be able to position themselves proportionally and become the main actors in utilizing their strategic environment to achieve sustainability and independence. Thus, through empowerment programs, local communities are encouraged to have the ability to utilize their resources and be fully involved in production, economic, social and ecological mechanisms (Raharjana \& Kutanegara, 2019). In accordance with the focus of the research, the community empowerment is aimed at developing natural potential in Banding Agung Village, Punduh Pidada Pesawaran District, especially water potential which is used for freshwater aquaculture activity. In practice, the were some strategies implemented in empowering the community based on freshwater aquaculture in Banding Agung as follows

\section{(i) Building the Community Awareness}

Building the community awareness is the first strategy of community empowerment intended to help the community know what potentials exist in the village environment to be developed (Astuti, Hermawan \& Rozikin, 2015). At this stage, an analysis of the strengths and weaknesseses of this potential was discussed using mapping activity. It began with discussions and socialization about how to initiate the empowerment of village communities in the management of existing village potentials, especially fresh water, through Pokdakan.

Pokdakan as mentioned earlier, is a fish farmer group formed on the initiative of several community members, especially those with freshwater fish farming. The process starts from gathering the community to discuss and socialize the importance of the group's existence in the context of community empowerment. The importance of establishing this group is in line with Mudege, Nyekanyeka, Kapalasa, Chevo \& Demo (2015) who state that farmer groups as part of civil society are able to provide opportunities for collective action and have the potential to empower and democratize the 
development. Besides, the forming of pokdakan was also motivated by the potential for the village area of Banding Agung, which has abundant water resources, supporting community empowerment efforts in the field of freshwater aquaculture.

Socialization is carried out to provide enthusiasm and awareness to the community about the importance of community empowerment and to invite people to think about what things the community can do to improve life welfare through increasing the potential in the village. During this outreach activity, there was an interactive question and answer session between the Field Extension Officer team and local residents. This indicated that the residents were quite enthusiastic about participating in the socialization. This was confirmed by Basuki, Rosa \& Alvin (2020) who maintan that the benefit of the socialization was the emergence of public awareness to empower themselves and the natural environment which was marked by the increasing number of people joining Pokdakan.

After the socialization and discussion were carried out, some of the residents agreed and strongly supported the establishment of the Pokdakan. The next stage is planning its formation management structure as well as the division of tasks and authorities of group administrators and planning group activities. After the group was formed, many people were interested in joining it in order that they could empower themselves there in improving their welfare.

One of the activities carried out in the Pokdakan group was the regular meeting once a moth aimed at discussing various issues related to freshwater aquaculture problems. The group discussions often held are when there are problems with cultivation disturbances, both pests and diseases that attack freshwater fish and also weather problems. Besides, when there is a dispute between Pokdakan members, it will be immediately discussed together to achieve the desired goals. Pokdakan Lestari Alam Sulah also held another discussion with another farmer group in some other neighboring villages. The problems solved concerning cultivation and technology, such as the problem of how to increase fish production. While the problem of technology is about how the flow of information technology can be absorbed by the group and can be applied in order to increase production. This corroborates Puspita \& Sunartomo's (2019) assertion that a group discussion is collective bargaining between two or more people to get the best decision. It is an agreed-upon joint decisionmaking in solving a problem. The method of joint decision-making is made when the decision concerns the interests of the community.

\section{(ii) Building Institutional Capacity}

Pokdakan Lestari Alam Sulah in Banding Agung Village, Punduh Pidada Subdistrict is a forum for self-empowerment of village communities as an effort to increase the capacity and quality of human resources for fish farming managers through knowledge and skills. In line with these efforts, pokdakan institutions need to be continuously strengthened and developed in order to continue to exist and provide benefits to their members.

Pokdakan institutions can be developed jointly through planning, implementation and evaluation activities. Therefore, through this capacitating stage, it is hoped that the Pokdakan institution can function properly and optimally in order to achieve the expected goals. Several activities have been carried out by this pokdakan in the context of capacitating its group members, such as providing training and fish farming management skills and sharing knowledge and experiences between members and from other village Pokdakan that have achieved success. This was supported by Astuti, Hermawan \& Rozikin (2015) who stated that capacity building could be achieved through education, training and other activities to improve individual or group skills, and empowerment.

Efforts to improve community welfare through freshwater fish farming are not only through improving the quality of human resources, but also related to the capital aspect which is very much needed to support the cultivation work. The working capital that the community uses to cultivate freshwater fish usually comes from their own circle. However, there are also some members who are interested in opening a fresh fish farming business by making loans from third parties.

Similarly, Kurniyati (2013) emphasizes that strengthening Pokdadan institutions can be done through strengthening economic capital by increasing institutional capital through increasing monthly contributions and social welfare contributions, strengtheninghumancapital by encouragingincreased knowledge and skills for both administrators and members in business management. and institutional development, as well as strengthening social capital by building members' awareness to be active in participating in the monthly meetings used as a forum for building closeness and bondage between all members by producing collective action for the common good.

The Pokdakan management has a role to assist members in making capital loans with other parties and even applying for financial assistance from the government. They can also find capital 
loans from other farmer groups with a mutually agreed payment scheme. In addition, they have also submitted proposals to get financial assistance from the government, but until now they have not received a good response. They hope that this assistance can be distributed evenly to all members for the purchase of fish feed and other needs related to the cultivation.

\section{(iii) Putting the Group Members' Knowledge and Skill and into Practice}

Provided with the knowledge and skills possessed, pokdakan members have the enthusiasm, motivation and high awareness to develop the cultivation business with their abilities. Pokdakan provides opportunities for members to access various existing information about marketing and the business world. This correlates with Aprilia (2019) who argues that the last stage in community empowerment efforts is the empowerment stage. At this stage the group is given the opportunity to apply the results of the training and the knowledge they have received from the training that has been given so that they can develop the skills contained in the group.

In addition, Pokdakan administrators provide opportunities for members to develop their businesses through cooperation with several parties, such as cooperation with pokdakan parties from other villages, cooperation with fish feed providers and field extension officers. The task of the Pokdakan committee is only to open roads, and then it is left up to group members to carry out the cooperation.

\section{Factors Inhibiting the Community Empowerment}

In carrying out an activity program, of course, not everything goes smoothly and as expected. In this case, there are several obstacles in the implementation of these activities. Referring to findings of the research, the followings are the factors inhibiting the freshwater aquaculture-based community empowerment in Banding Agung Village.

\section{(i) Lack of Community Participation}

Based on the field findings, it is known that the main obstacle for developing the aquaculture business is the lack of community participation in Pokdakan group activities. This happens due to the lack of public awareness to improve self-quality through the group's activities, for example group discussion. Several members said that their inactivity was due to the activities in their main jobs so they rarely attended group meetings. This can be seen from the minimal percentage of community attendance in group meeting activities.
Brainstorming activities among group members were still carried out but were limited due to the busy activity of main job and tired condition of the farmers. Members attending the meeting were at least 2 or 3 people, often no one even came. As a result, the managers and members of the farmer group do not really understand the function of the Pokdakan so that they go back to running independently the farming business.

This finding is in line with Amelia's (2020) statement that obstruction of Pokdakan activities can occur due to internal factors, where most members are busy with their main work so that group activities are neglected. Not all people are fully aware of the importance of improving the quality of human resources in an effort to improve their welfare (Ibrahim, Sutarna, Abdullah, Kamaluddin \& Mas'ad, 2019). In fact, from the meeting, many benefits were obtained, such as sharing knowledge and skills, as well as capital assistance to run fish farming better.

\section{(ii) Lack of Knowledge and Capital}

The purpose of education is to acquire knowledge. However, to gain knowledge is not only obtained through formal education but also informally, such as through books, experiences of other people, and technology media. Members of the fish cultivator group in the village still do not have any more desire to seek knowledge or insights from other sources. They only rely on information obtained through training, counseling and socialization activities carried out by Pokdakan, so that the information obtained is only from one source which causes them to be less developed. Similarly It was also stated by Erwan (2017) that the limited capacity of community resources in reality on the ground had resulted in the ineffectiveness of each stage of the activity, difficulties in communicating and socializing the program, and ultimately causing less effective participation.

In addition, the limited ability or capital capacity made fish farmers unable to invite facilitators or bring in fish farmers from other areas to teach and exchange ideas with Pokdakan members at Banding Agung. This made the people who were members of the Pokdakan choose to surrender and run and maintain their fish farming ponds by relying on the experience of each member. This finding strengthens Dianti \& Effendi (2019) who maintain that the lack of qualified human resources means that many opportunities cannot be utilized optimally by the community due to limited knowledge and skills. 


\section{(iii) Minimum Assistance and Counseling}

The quality of human resources will be well established, especially in the case of freshwater fish farming when the government is involved in it. These empowerment activities will run effectively if not only the community plays an active role in it but also government involvement. In this case, the government is expected to continuously conduct socialization activities on good fish farming management through PPL (extension officers) to increase public awareness.

Assistance is something that is quite important in an effort to increase the productivity and welfare of the community through Pokdakan. Assistants in this component are referred to as facilitators, communicators and motivators. Basically, mentoring is an effort made to involve the community to play an active role in developing the various potentials available in the area to achieve a better life for the community.

The findings in the field suggest that the majority of Pokdakan members are elementary school graduates with limited knowledge. They only rely on the experience they have in managing fish farming. In fact they have asked village officials several times but no assistance has been given. In addition, the absence of agricultural extension officers at Banding Agung meant that farmers had to invite these officers from other villages, thus requiring a fairly large allocation of time and transport costs to come to Banding Agung. This has an impact on the lack of PPL visits for assistance. According to Astuti, Hermawan \& Rozikin (2015), the less involvement of agricultural extension agents as farmer assistants will cause them less focused on assisting farmer groups so that many Pokdakan activities are neglected.

\section{(iv) Less Involvement of the Village Government}

Government through village officials also needs to encourage the community to be actively involved in participating in training which is very useful for Pokdakan members. It is also hoped that the government will respond well to the wishes of pokdadan members to get capital assistance to develop freshwater fish cultivation. The fish cultivator community actually wants the attention of the government, both the village and the parties involved, in this case the agricultural office.

However, the fact is that the absence of the government in the empowerment and assistance process makes the community then run on its own according to their experiences. They feel desperate to expect assistance from the village government, because they feel they are not considered there.
Never mind help to call fish farming experts, fish feed is never assisted.

Broadly speaking, farmers in Banding Agung Village who are members of the Pokdakan expect the village government to participate in discussion events so that they can direct and give advice on good Pokdakan management. However, this cannot be realized for reasons other than time related, the village government has a fear of providing direction because of the lack of expertise and fields controlled by the village government, so that it raises concerns over giving directions or answers when farmers ask questions.

Principally, village officials can play the role of leaders who are emulated by their residents. They can be a driving force for the community to make changes for the better. This was strengthened by Fitria, Setiawati \& Firdaus's finding (2019) claiming that the main role of village officials is to raise awareness and enthusiasm for the community to play an active role in village development activities, especially those related to freshwater fish farming that has been facilitated by the Pokdakan in the village. Therefore, village officials are also expected to be able to open networks with other parties so that regional potential, especially freshwater fish cultivation, can be maximized as part of efforts to advance village development.

\section{CONCLUSION}

Referring to the data analysis, the study has found some strategies implemented in empowering the community based on the freshwater aquaculture activity, consisting of building the community awareness on the importance of pokdakan, building institutional capacity through education, training and workshop of fish farming management, and putting group members' knowledge and skill into practice, as well as the factors inhibiting the community empowerment, namely lack of community participation, lack of knowledge and capital, minimum assistance and counseling, and less involvement of the village government. The limitation of the study lies in the sample selection, which is only one pokdakan group so that it has not been able to make generalization of the empowerment strategy that is suitable for all pokdakan in Punduh Pidada sub-district. Further research might be able to make a more comprehensive study involving all pokdakan in other villages within the scope of the Punduh Pidada sub-district so that a more effective and efficient model for developing empowerment strategies can be created. This research is expected 
to provide strategic solutions in an effort to motivate the community to actively participate in supporting regional development, particularly the development of rural communities through freshwater aquaculture activity. From this research, it is hoped that the communitywill realize theimportance ofempowering rural communities so that they have the ability, expertise and independence to develop the existing potential to increase income and welfare. In addition, this research is expected to inspire the emergence of empowerment models of rural communities that are more efficient for further research.

\section{REFERENCES}

Amelia, L. (2020). Peran Pemerintah Desa dalam Meningkatkan Kesejahteraan Masyarakat pada Sektor Budidaya Ikan: Studi Desa Kubu Kandang Kecamatan Pemayung Kabupaten Batanghari. Skripsi. Universitas Islam Negeri Sultan Thaha Safuddin Jambi.

Aprilia, R. (2019). Pemberdayaan Masyarakat pada Kelompok Budidaya Ikan (Pokdakan) Sudi Makmur di Dusun Priangan desa karanganyar Lampung Selatan. Skripsi. Universitas Islam Negeri Raden Intan Lampung.

Astuti, L.I., Hermawan, \& Rozikin, M. (2015). Pemberdayaan Masyarakat dalam Pembangunan Pertanian Berkelanjutan. JAP: Jurnal Administrasi Publik, 3, (11), 1886-1892.

Basuki, K.H., Rosa, N.M. \& Alfin, E. (2020). Membangun Kesadaran Masyarakat dalam Menata Lingkungan yang Asri, Nyaman, dan Sehat. JMM: Jurnal Masyarakat Mandiri, 4, (1), 1-9.

Dianti, F. \& Effendi, N. (2019). Analisis Pemberdayaan Masyarakat Desa Sri Tanjung Kecamatan Rupat Kabupaten Bengkalis. Kolaborasi: Jurnal Administrasi Publik, 5, (3), 319-332.

Erwan. (2017). Faktor Penghambat Pelaksanaan program Nasional Pemberdayaan Masyarakat Pembangunan Infrastruktur Sosial Ekonomi Wilayah di Kabupaten Tabalong Kalimantan Selatan. DIA: Jurnal Administrasi Publik, 15, (2), 1-7.

Fitria, Setiawati, B. \& Firdaus, M. R. (2019). Peran Kepala Desa sebagai Pengambil Keputusan dalam Pemberdayaan Masyarakat di Desa Tangkan Kecamatan Awang Kabupaten Barito Timur. JAPB, 2, (2), 640-656.
Ginting, R., Huda, M., Drifanda, V. \& Affandi, R. (2020). Pemberdayaan Masyarakat Desa Jungsemi di Masa Pandemi Covid-19 Melalui Pelatihan Pembuatan Hand Sanitizer dan Pelindung Wajah. IJECS: Indonesia Journal of Empowerment and Community Services, 1, (1), 20-27.

https://pesawarankab.bps.go.id/ (accessed on January 5, 2021).

Ibrahim, Sutarna, I.T., Abdullah, I., Kamaluddin \& Mas'ad. (2019). Faktor Penghambat dan Pendukung Badan Usaha Milik Desa pada Kawasan Pertambangan Emas di Sumbawa Barat. Sosiohumaniora, 21, (3), 349-354. doi:http://dx.doi.org/10.24198/ sosiohumaniora.v21i3.23464

Kurniyati, Y. (2013). Penguatan Kapasitas Kelembagaan Kelompok PEW untuk Mengembangkan Ekonomi Lokal Kota Yogyakarta. Jurnal Maksipreneur, 3, (1), 90-120.

Laksono, B. (2018). The Community Empowerment Through Social and Educational Institutions. Jurnal Pendidikan Humaniora, 6, (3), 115-122.

Mudege, N.N., Nyekanyeka, T., Kapalasa, E., Chevo, T. \& Demo, P. (2015). Understanding Collective Action and Women's Empowerment in Pottato Farmer Groups in Ntcheu and Dedza in Malawi. Journal of Rural Studies, 42, 91-101.

Nassaji, H. (2015). Qualitative and Descriptive Research: Data Type Versus Data Analysis. Language Teaching Research, 19, (2), 129132. https://doi.org/10.1177/1362168815572747

Prihantoro, S. (2013). Strategi Pemberdayaan Masyarakat Miskin dalam Meningkatkan Pendapatan (Studi Empiris di Kelurahan Bandung Kecamatan Kutoarjo Kabupaten Purworejo). Journal of Nonformal Education and Community Empowerment, 2, (2), 15-21.

Puspita, M. C., \& Sunartomo, A. F. (2019). Peran Kelompok Pembudidaya Ikan (Pokdakan) Aci Bahari dalam Pembudidayaan Ikan Bandeng di Desa Pesisir Kecamatan Gending Kabupaten Probolinggo. Jurnal Sosial Ekonomi Pertanian, 12, (2), 80-91.

Raharjana, D.T. \& Kutanegara, P.M. (2019). Pemberdayaan Masyarakat di Kawasan Cagar Budaya. Jurnal Tata Kelola Seni, 5, (1), 50-65. 
Setiyawan, B. (2016). Pengembangan Budidaya Ikan Air Tawar Rekreatif di Karanganyar. Skripsi. Universitas Muhammadiyah Surakarta.

Squalli, J. (2020). Evaluating the Potential Economic, Environmental, and Social Benefits of Orange-spotted Grouper Aquaculture in the United Arab Emirates. Marine Policy, 118, 1-9. https://doi.org/10.1016/j. marpol.2020.103998.

Sugiyono, P. D. (2017). Metode Penelitian Bisnis: Pendekatan Kuantitatif, Kualitatif, Kombinasi, dan $R \& D$. Penerbit CV. Alfabeta: Bandung.
Sutarjo, G.A. \& Samsundari, S. (2018). Peningkatan Produksi Budidaya Ikan Tawar melalui Penerapan Manajemen Kualitas Air dan Pembuatan Pakan Ikan Mandiri di Kelompok Pembudidaya Ikan Sumber Rejeki dan Cinta Alam Kecamatan Bungatan Kabupaten Situbondo. Jurnal Dedikasi, 15, 1-4.

Worang, B.C.G.S, Sinjal, H.J. \& Monijung, R.D. (2018). Strategi Pengembangan Budidaya Perikanan Air Tawar di Kecamatan Dimembe Kabupaten Minahasa Utara Provinsi Sulawesi Utara. Budidaya Perikanan, 6, (2), 68-76. 